\title{
Obituary
}

\section{Dr. W. Schmidt}

$\mathrm{T}$ $\mathrm{HE}$ news of the death on November 27 of Dr. Wilhelm Schmidt, the director of the Central Institute of Meteorology at Vienna, comes as a great blow to his friends and colleagues in meteorology and geophysics. Many of us had seen him recently at Edinburgh at the meeting of the International Union of Geodesy and Geophysics, quite recovered from his illness, keen and interested as always, full of energy and to all appearances with a long period of active scientific work still before him.

Wilhelm Schmidt was born on January 21, 1883 . His forbears, as his name indicates, were smiths, in a village some $12 \mathrm{~km}$. from Innsbruck. His grandfather, a man of great courage and determination, decided to go to the University at Innsbruck to study, and began to walk there and back every day, working in the smithy before he started and after he got back. Schmidt may be said to have inherited from him his determination and his capacity for work.

After an education at the University of Vienna, Schmidt entered the Central Institute for Meteorology and Magnetism and was appointed assistant in 1909. I first met him there at the beginning of 1909 when Trabert was director and Julius Hann, former director and editor of the Meteorologisches Zeitschrift, had his room at the Institute. Among Schmidt's colleagues in the Institute were Exner, Defant, Wagner, R. Schneider, Hanzlik and von Ficker-a notable company.

Schmidt's main interest at that time, as indeed in later years, lay in the study of the structure of the atmosphere. It was a time when the first fruits of the international investigation of the upper air were being gathered. He was anxious to test their basis and invited me to collaborate with him in finding the lag of the instruments which were being used. The result proved to our satisfaction that the stratosphere could not be explained away as due to lag in the instruments.

Shortly afterwards, Schmidt turned his attention to an examination of barometric waves of relatively short period, particularly in the neighbourhood of Innsbruck. He found that the waves agreed with the waves which would be expected at the boundary between two currents of different density and that observations of cloud confirmed his deductions. He gave an account of his experiments at the Sheffield meeting of the British Association in 1910.

During and after the Great War, Schmidt became specially interested in the phenomena of turbulence and worked on this subject at about the same time as G. I. Taylor was working on it in Great Britain. The results of his work he embodied later in a book entitled: "Der Massenaustausch in freier Luft und verwandte Erscheinungen". Schmidt attacked the problem of turbulence in a slightly different way from that adopted by Taylor. His development of the theory was based on the assumption that an eddy carried with it (at least throughout the period of life in which it is of interest) the momentum with which it enters the field of observation. The quantity which he defined as Austausch is equal to the eddy viscosity multiplied by the density. The lead which Schmidt gave has been followed by other writers such as Prandtl and von Kármán.

In this as in other branches of meteorology, Schmidt always wanted to get behind the formulæ and the mathematics to the underlying physical principles. This is illustrated by a remark of L. F. Richardson's about the independence of the coefficient of eddy diffusion of the quantity diffused: "This was explained by G. I. Taylor and later W. Schmidt gave the general notion behind any mathematical argument in the form that an exchange of mass goes on, and that the measure $c$ will be the same for any properties which this mass simply carries with it."

In 1930 Schmidt was appointed editor of the Meteorologische Zeitschrift in collaboration with Süring, and under his editorship the Zeitschrift maintained its high position as the leading monthly meteorological journal of the world.

In 1924 Schmidt was appointed professor of meteorology at the Agricultural College at Vienna, and he became particularly interested in problems of local climatology. During this period and the period while he was director of the Institute after the death of Exner in 1930, he gave himself whole. heartedly to investigations in this subject. It was at a time when funds for scientific research were very difficult to secure in Vienna, but he managed to get some help from the Deutsche Notgemeinschaft and he fitted out a travelling observatory for investigating the practically simultaneous variations in conditions in different parts of Vienna and the neighbourhood. Later on, he extended these investigations of local climate and micro-climatology to some parts of the Austrian Alps, and he gave a lecture before the Royal Meteorological Society in March 1934 briefly de. scribing this work. In the following year he described the results of his investigations of turbulence and of the flow of air in the neighbourhood of the ground in a paper read before the Royal Aeronautical Society.

Early in 1935, after the death of Prof. Wallen, Schmidt took charge of the International Commission for Agricultural Meteorology, of which he had been secretary, and he was elected president at the meeting of the Commission in Danzig in 1935. At the end of 1935 he was awarded the Symons Gold Medal of the Royal Meteorological Society, perhaps the highest meteorological award of any in the world. His most recent work was a book written in collaboration with Dr. Brezina on "Kunstliche Klima in der Umgebung des Menschen", a copy of which he sent to me with a friendly note on November 25, only two days before he died. 
Schmidt loved the country and the mountains as he loved his work and intercourse with his colleagues. He was a great meteorologist and a lovable man. His loss will be keenly felt by all who knew him personally and by many who knew him only through his published work. It is a blow which falls particularly severely on Vienna, the more so coming as it does after the sudden and unexpected death of Exner six years ago.

E. GOLD.

Prof. J. T. Cash, F.R.S.

JoHn Theodore CASH, emeritus professor of materia medica and therapeutics in the University of Aberdeen, who died on November 30, was a man of wide sympathies and, to those fortunate to know him intimately, a delightful companion. Born in Manchester in 1854, he studied arts and medicine at Edinburgh, qualified as M.B., C.M. in 1876, and proceeded to M.D., his thesis for which earned a gold medal, in 1879. After qualification he worked and studied at Paris, Vienna, Berlin and Leipzig.

Cash's early interests were in physiology and hygiene, but later they became almost purely pharmacological. The post-Continental period he spent in London, and investigated the pharmacological action of organic lead compounds, the action of chemical disinfectants (which he reported to the Local Government Board), and contributed, with Lauder Brunton, an important paper on the connexion between chemical constitution and physiological action to the Royal Society. He was elected a fellow of the Royal Society in $\mathbf{1 8 8 7 .}$

The appointment of Cash to the chair of materia medica and therapeutics at Aberdeen in 1886 was a surprise, for the chair had previously been held by medical practitioners, and Theodore Cash was a pure researcher. The appointment was, however, fully justified. Although only a part-time job, he devoted himself wholly to university work. A student of his first class was Arthur Cushny, who became successively professor of pharmacology in the University of Michigan, in University College, London, and lastly professor of materia medica and therapeutics in the University of Edinburgh.

At Aberdeen, Cash continued his investigations on chemical constitution and physiological action, then on the action of the pure organic nitrites prepared by Dunstan, and later on the action of the aconitines, which also had been prepared by Dunstan. The results were incorporated in papers to the Royal Society. They show that thoroughness and attention to detail which is characteristic of all Cash's work. He also investigated and wrote, among other matters, on tobacco smoking and skin irritants. His administrative work was equally thorough. For a time he was dean of the Faculty of Medicine and the University's representative on the General Medical Council. His work was acknowledged by the LL.D. of Edinburgh and, after retirement, of Aberdeen.

Cash was renowned as a fisherman as well as a pharmacologist. Once, the present writer when at a fisherman's inn in Scotland inquired from a visitor what fly he used and he replied "Cash's". On relating the incident to Prof. Cash, he confessed to having prepared and tried his own flies. This incident illustrates the man; he was as modest of his prowess with the rod as of his abilities in other spheres. $\mathrm{He}$ fished nearly all the streams of the British Isles, and up to a few years ago could still be found occasionally on the banks of his beloved Don.

Prof. Cash married the youngest daughter of the Right Hon. John Bright. Her death, soon after their removal to Hereford, was a great blow to him. There are four children of the marriage, two sons and two daughters, to whom we extend our sympathy.

C. R. M.

\section{Dr. G. Schack-Sommer}

Dr. Gustaf Schack-Sommer died in London on October 16, aged eighty-two years. The sugar industry, home-grown sugar in particular, and his many friends will regret the passing of one who was blessed with a charming personality and presence, and whose interest in sugar was maintained to the last. $\mathrm{He}$ was unmarried. It was his intention to be present at the International Conference of Sugar Analysts in London in September, but unfortunately he was prevented by ill-health at the last moment. His family home was at Marienlyst, Elsinore, in Denmark, but at the time of his birth in 1854 his father was Danish Consul in Hamburg, and it was there that he spent his school life, although the summer vacation was always spent at Elsinore. In 1872 he was attracted to Heidelberg by the work of Bunsen, Kirchhoff and Kopp, and in 1875 he graduated and obtained his Ph.D. degree. His first professional post was in a German chemical works.

In 1877 Dr. Schack-Sommer decided to live in England and took the opportunity offered him to assist at one of the first alkali works in this country, the Newcastle Chemical Works. In 1878 he left Newcastle for Liverpool, where he joined the sugarrefining firm of Crosfield, Barrow and Co., of which he became a partner in 1884. In the same year he renounced his Danish nationality in favour of English. In 1881 he assisted in the foundation of the Society of Chemical Industry; he became a fellow of the Institute of Chemistry a few years later.

Dr. Schack-Sommer's early years in Germany had impressed upon him the benefits resulting from the growing of sugar beets, and from 1889 until 1895 he was instrumental in the growing of sugar beet in Lancashire and Ireland. Each year the results were carefully tabulated, supporting his contention that the crop was as suitable for England as for the Continent. With other pioneers, of whom Lord Denbigh and Sir George Courthorpe were the chief, he never missed an opportunity either at lectures or meetings of impressing all concerned with the merits of beet growing in this country. In 1890 he delivered a lecture which was attended by many members of Parliament interested in agriculture, and he was one of the earliest members of the British Sugar Beet Council, becoming chairman of the Liverpool section in 1895. He frequently recalled the pleasure it had 